\title{
RESEARCH PAPER \\ Female calling and male flight orientation and searching behaviors in Callisphyris apicicornis: evidence for a female-produced sex attractant pheromone
}

\author{
Tomislav Curkovic, and Catalina Ferrera \\ Depto. Sanidad Vegetal, Facultad de Ciencias Agronómicas, Universidad de Chile, Casilla 1004, Santiago, Chile.
}

\begin{abstract}
T. Curkovic, and C. Ferrera. 2012. Female calling and male flight orientation and searching behaviors in Callisphyris apicicornis: evidence for a female-produced sex attractant pheromone. Cien. Inv. Agr. 39(1): 147-158. Callisphyris apicicornis is a fruit pest of increasing concern in Chile. To aid in the identification of its sex pheromone for use in the management of this insect, "calling" (pheromone release) of females and "orientation and searching" behaviors of males to calling females were video recorded. Light intensity, wind speed, temperature, time of the day, and the frequency of individuals performing each step within both behavioral sequences were recorded as well. Drawings of the behavioral steps and ethograms (routes and returns) are also provided, including transition frequencies between behavioral steps. The calling behavior of females included diagnostic movements of the abdomen, legs, elytra, and wings, showing similarities to the descriptions of other cerambycid species in which females call. The orientation and searching behavior of males included zigzagging flights (characteristic steps observed in insects responding to airborne pheromone plumes) and landing on and searching for females in cages. Females called and males responded mainly between 9 AM and 1 PM. Both behaviors were performed in a non-random fashion and were stereotyped. Calling behavior was significantly affected by light (apparently triggering the behavior) but not by wind speed, ambient temperature, or female age. Males tended to respond most strongly to younger females, although these called significantly less frequently than older ones. These results strongly support the existence of a female-produced sex pheromone in C. apicicornis and provide the background information to aid in attempts of pheromone collection and identification. Male behavior characterization also provides a base-line to compare with tests to evaluate the activity of putative pheromones for this species. This study is one of the first reports of a cerambycid species in which the female calls and the male consequently responds to her and the first one on the characterization of the calling and oriented searching behaviors for a Necydalinae.
\end{abstract}

Key words: Cerambycidae, Insect age, light intensity, pheromone, sexual behavior.

\section{Introduction}

Callisphyris apicicornis (ex vespa) (Fairmaire \& Germain) (Coleoptera: Cerambycidae) is a

Received January 21, 2011. Accepted November 1, 2011. Corresponding author: tcurkovi@uchile.cl xylophagous and polyphagous species native to Chile, with increasing importance as a pest in orchards (e.g., Cydonia oblonga Mill., Feijoa (Accra) sellowiana Berg.) and ornamentals (e.g., Betula spp. and Cotoneaster spp.) (Barriga et al., 1993; Artigas, 1994; Curkovic, 2008). This species feeds on at least 19 known plant hosts, 
including some native and several exotic species (Barriga et al., 1993). Larvae bore into branches, the trunk, and, partially, roots, infesting exclusively living wood (Barriga et al., 1993). In some cases, they cut off the trunk or destroy many roots, severely affecting the architecture or even killing the plant (Curkovic, 2008). Because eggs, larvae, and pupae are difficult to reach with conventional control techniques (Curkovic and Ferrera, 2008), tools for adult management and control are needed because adults live for approximately 2-3 weeks, which is a relatively short period that would facilitate controlling them when necessary (Curkovic and Ferrera, 2008).

Sex pheromones control several phases and behaviors of adult insect life within species. Therefore, these compounds might be useful for controlling pests at the adult stage, as suggested by Lacey et al. (2004) for some cerambycids, particularly those for which neither conventional chemical nor biological control are either feasible or available (Curkovic and Ferrera, 2008). When developing these pheromone-based control techniques, the goal is frequently to disrupt normal sexual behavior. Therefore, careful characterization of C. apicicornis sexual behavior is a necessary first step in the identification and development of applications that would use sex pheromones against this type of insect. However, the reproductive behavior of $C$. apicicornis has not been fully described (although recently, C. apicicornis courtship and mating has been characterized by Curkovic and Muñoz (2011)), and only a few references have been published on this topic for other cerambycid beetles (Michelsen, 1965). Thus, a detailed description and analysis of two behaviors is needed for C. apicicornis: a) "calling", which is performed frequently by females and usually involves postures oriented to maximize pheromone release and diffusion (Connor and Best, 1988), and b) "oriented flight searching", which is usually performed by males, including maneuvers while flying that maximize the chance to follow and locate pheromone sources (Kennedy,
1983). Therefore, the objectives of this research were the following: a) to describe both calling (in females) and oriented flight searching (in males responding to calling females); b) to associate female calling with male oriented flight searching, female age, and environmental conditions (light intensity, wind speed, and ambient temperature), and c) to correlate male-oriented flight searching with female age.

\section{Materials and methods}

\section{Insect sampling and rearing}

Branches from living trees showing symptoms of C. apicicornis infestation (Barriga et al., 1993), i.e., the release of boring dust through small holes in the bark and the presence of branches with fresh, neat, and transversal cuts, which are made by larvae, were collected from known tree hosts (C. oblonga, Tamarix parviflora DC, Cotoneaster spp., and $F$. sellowiana) at several locations near Santiago $\left(34^{\circ} 14^{\prime} \mathrm{S}, 70^{\circ} 38^{\prime} \mathrm{W}\right)$ at the beginning of spring (August-September) in 2007 and 2008. Most samples contained both last instar larvae and pupae, which are stages that are easily reared under confined conditions (Flanders cages). Adults emerged from September through December in the laboratory at approximately $20 \pm$ $5^{\circ} \mathrm{C}$ and $50 \pm 5 \% \mathrm{RH}$, as recorded with a Boeco, BOE 330 (Germany) digital thermo-hygrometer. During this period, the cages were checked daily to collect freshly emerged adults, which were sexed (C. apicicornis is sexually dimorphic, with males being smaller and with longer antennae than females) and kept individually in 500 $\mathrm{mL}$ plastic vials. The adults were fed with a $5 \%$ sugar solution via cotton wicks. Individuals of both sexes and different ages (expressed as days after emergence) were used, some of them several times, in the field. Specimens were not allowed to mate before field tests to keep them sexually active. The age ranges of the individuals were 1 to 13 days and 1 to 5 days for females and males, respectively. 


\section{Field observations}

Field observations were conducted from October through December each season at the Facultad de Ciencias Agronómicas, Universidad de Chile, Santiago, Chile. The goal was to record the behaviors (calling in females and oriented flight searching in males, with both studies being conducted independently) of test animals during encounters between males and females leading to attempts to mate. Both male and female $C$. apicicornis were active (making movements or flying) between 8 AM and 2 PM (Figure 1); thus, field observations were conducted between these hours. Callisphyris apicicornis adults are mostly motionless during the rest of the day (Ferrera, 2009). The procedure for the field trials was similar in both studies ("female calling" and "male oriented flight searching"), which started by placing one to three virgin females on the foliage of a potted Betula spp., approximately $1.5 \mathrm{~m}$ above the ground. Some virgin females were reused the following days. In the calling study, the females were placed on the foliage with no restraints (wild/reared arriving males were captured before mating), while during the oriented searching study, they were set inside a large cylindrical wire screen (50 cm length $x 70 \mathrm{~cm}$ diam.) to avoid mating. This step was critical because the number of females available was limited during the male oriented flight searching study. In both studies, a smaller wire screen cage $(10 \mathrm{~cm}$ length $\mathrm{x} 5$ $\mathrm{cm}$ diam.) containing one virgin male was held by a person $3 \mathrm{~m}$ downwind, at approximately the same height as the female. Female calling behavior was recorded after at least $30 \mathrm{~min}$ of acclimation time. When studying male oriented flight searching, once the cage was open, the specimen was given a $5 \mathrm{~min}$ response period. Only males flying to the source were recorded. The observers were located at approximately 1 and $3 \mathrm{~m}$ from females and the male release point, respectively. Arrivals of wild males to calling females were also recorded during the male oriented flight searching study. Drawings of all steps for each behavioral sequence (female calling and male oriented flight searching) were produced.

\section{Data collection}

Behavioral sequences were filmed using a Sony Handycam video recorder (HDR-SR10 (Japan)) and later played back on an LG LCD TV (Mod. 26LG30R (Korea)), which allowed for the identification of homogeneous, observable, and discrete (with a clear beginning and a clear end that precluded overlapping) steps, as proposed by Haynes and Birch (1984). Preliminary observations allowed for the identification of specific steps that formed the sequence (i.e. "mating sequence" or "behavioral sequence") in C. apicicornis. Later, the frequencies of specific steps were recorded in separate tables, one for each behavior studied (calling and oriented flight searching). The value in each cell (within the respective table) represents the number of individuals performing that particular step that have also performed the specific previous step (as described by Fagen and Young, 1978). The duration of each sequence from the first to the last step was also measured with a chronometer (Digi Sport Instrument, DT 483, China). Temperature and wind speed were measured with an Extech Instrument, Mod. 407119, hotwire thermo-anemometer (USA), and light intensity was measured using a VWR International, Mod. 944, light-meter (USA). All environmental

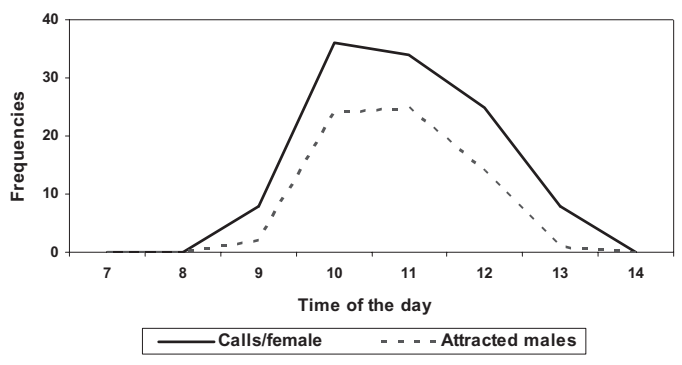

Figure 1. Number of C. apicicornis calls/female and males responding $v s$. time of day. 
conditions were registered every hour during field studies and observations to later test their possible influence on the occurrence (or lack of occurrence) of both behaviors.

\section{Data analysis}

Frequencies of behaviors (female calling and male oriented flight searching) were converted into transitional tables of preceding (in rows) and succeeding (in columns) behavioral steps. Because both behaviors had 6 steps, a $6 \times 6$ table was built for each behavioral sequence. The complete tables were analyzed for firstorder dependence (Mondor and Roland, 1998). The chi-square test and the Fisher test, when chi-square assumptions were not met, were both performed with SPSS Statistics software (IBM Co., version 15, USA; Visauta, 2007). The respective transition frequencies (i.e., the cell value divided by the total from that particular row) that were significant (i.e., those with $\mathrm{P} \leq 0.05$ after the statistical test for cells) are presented in ethograms (as in Fagen and Young, 1978, and Haynes and Birch, 1984) for both female calling and male oriented flight searching. The ethograms show the routes, transitional frequencies, and the returns within the sequence. The stereotypy index (SI) used by Mori and Saito (2005) was calculated (SI = $\sum \mathrm{SI}_{\mathrm{i}} * \mathrm{~F}_{\mathrm{i}} \cdot \mathrm{SI}_{\mathrm{i}}=\sqrt{ }\left(\left[\left\{\sum\left(\mathrm{P}_{\mathrm{ij}}\right)^{2}-\left(\sum \mathrm{P}_{\mathrm{ij}}\right)^{2}\right\} / \mathrm{r}_{\mathrm{i}}\right] /[1-(1 /\right.$ $\left.r_{i}\right)$ ]), where $P_{i j}=$ transition frequency or conditional probability from step "i" to all other possible steps “ $\mathrm{j}$ ”, $\mathrm{r}_{\mathrm{i}}=$ repertoire or number of all possible transitions from the preceding step " $i$ ", and $F_{i}=$ number of times step "i $i$ " occurs/total of sequences for a given behavior) to estimate the repeatability of the behavioral sequences. The criteria proposed by Ferrera (2009) were used to categorize sequences as either highly (SI $\geq 0.89)$ or moderately $(0.76<$ SI $<0.89)$ stereotyped. Finally, binary logistic regression (Visauta, 2007) was used to correlate the following parameters: 1) calling behavior (occurring vs. not occurring) as the dependent variable vs. male oriented flight searching (occurring vs. not occurring), environmental data (light intensity, wind speed, and ambient temperature), and female age as independent variables and 2) male oriented flight searching (occurring vs. not occurring) in males (dependent variable) $v s$. female age (independent variable). This statistical procedure was used to identify variables that were significant on the occurrence of both behaviors.

\section{Results}

\section{Calling behavior in females}

The postures or movements (Figure 2) made by females $(n=25)$ as males approached were 1) motionless, MO; 2) movement of the abdomen, MA, which involves raising and lowering rhythmically while all the appendages remain still; 3) movement of abdomen and legs, MAL, which is similar to MA but includes simultaneous lifting and lowering of the third pair of legs alternately (left and right); 4) movement of abdomen, legs, and elytra, MALE, which is similar to MAL but also includes lifting and lowering of the elytra; 5) movement of abdomen, legs, elytra and membranous wings, MALEW, which is similar to MALE, but includes extending, lifting, and then lowering the membranous wings; and 6) female walks, FW, from the point where it remained stationary during steps 1 through 5. These postures or maneuvers are assumed to constitute the "calling behavior" in C. apicicornis because they were not observed between $2 \mathrm{PM}$ and $8 \mathrm{AM}$, when females and males tend to be mostly stationary without interacting. It is also interesting to note that no female flew toward a caged male, while almost all males flew toward calling females, even after testing a relatively large number of individuals (at least 60 females and over 100 males) over two seasons of field observations, which supports the hypothesis of the female calling and the male responding to her. 

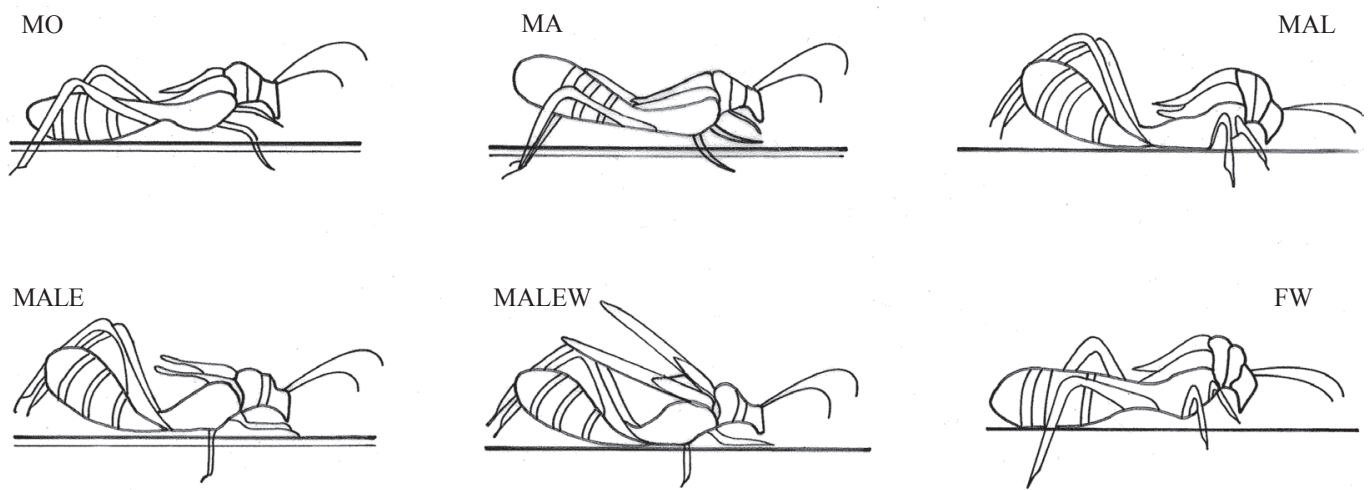

Figure 2. Drawings of calling behavior in C. apicicornis females. Motionless (MO); Movement of abdomen (MA); Movement of abdomen and legs (MAL); Movement of abdomen, legs, and elytra (MALE); Movement of abdomen, legs, elytra, and membranous wings (MALEW); and Female walks (FW).

To our knowledge, this is the first description of female calling occurring within beetles of the Necydalinae subfamily (although Cerda [1986] states that $C$. apicicornis belongs to the subfamily Lepturinae, tribe Necydalini, recently, Bousquet et al. (2009) have reclassified Necydalinae as its own subfamily; consequently, the later criteria are used herein). A total of 59 successful (ending in male attraction) calling sequences were recorded, lasting on average, $1.6 \pm 1.2 \mathrm{~min}$. The ethogram for the calling behavior (Figure 3) performed by females, shows only significant transitions in which most individuals followed the transition MO to MAL and then went back to MO. All females performing MALEW went back to MALE. The remaining alternative routes were much less frequent $(<20 \%)$. The chi-square test demonstrated that there was a general first order dependence between the steps included within the whole female sequence $(\mathrm{P} \leq 0.05$; contingency coefficient: 0.78 ), indicating that the sequence was not random. The SI value for the sequence performed by females was 0.83 , which is considered moderately stereotyped (Ferrera, 2009).

To date, reports of the sex pheromone released by cerambycid beetles through calling have focused mainly on the male performance of this behavior in the subfamily Cerambycinae (Neoclytus acuminatus F., N. mucronatus F., and Xylotrechus colonus F.) (Lacey et al., 2009). In these species, males tend to be stationary during calling
(Millar et al., 2009), while adopting a "push-up stance" with the front legs extended and both the head and thorax raised. There are also a number of reports of male-produced pheromones (e.g., Hall et al., 2006; Ray et al., 2006). On the other hand, calling behavior by females has been less commonly reported for cerambycid beetles and has been described in detail in only a few cases. For instance, Prionus californicus Motschulsky females lower their heads and raise their abdomens while extending their ovipositors, remaining stationary in this position for up to $10 \mathrm{~min}$. During this period, they contract their abdomens rhythmically while flexing the ovipositor (Barbour et al., 2006). Thus, calling postures in P. californicus and C. apicicornis share some common rhythmic movements of abdomen and the third pair of legs. These movements have also been observed in

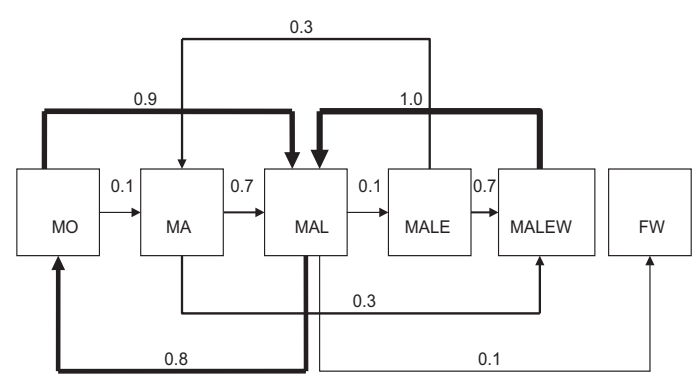

Figure 3. Ethogram for female calling in C. apicicornis. The figures above the lines connecting the steps (routes) within the sequence indicate the respective transition probabilities. The thicker lines indicate greater probabilities between steps, while the arrows show the direction of each transition. Details are provided in Figure 2. 
other cerambycids and other Coleoptera during sexual behavior (Michelsen, 1965; Facundo et al., 1999). Calling in P. californicus also partially matches the calling sequence of $C$. apicicornis, in which females remain stationary while exposing (occasionally in C. apicicornis) the ovipositor. All of these steps are likely to maximize both the pheromone release and its diffusion by exposing the body parts involved in pheromone release (e.g., the male glands are located on the prothorax; Ray et al., 2006) to the convective air layer next to the insect. The only record of a putative pheromone gland in cerambycid females describes its placement on the ovipositor (Cervantes et al., 2006). Interestingly, during our observations, some C. apicicornis females exposed parts of the ovipositor for a few moments, and some of the lobes observed at the end of this structure look like glands. However, this aspect remains unclear and requires further study.

The trend proposed by Barbour et al. (2006), who considered the female pheromone release during calling an ancestral condition for cerambycids, is supported by our data. Callisphyris apicicornis shares this strategy, and it also belongs to a relatively primitive subfamily (Bousquet et al., 2009). However, the adaptive advantage of such strategy for this species and its overall frequency in the Necydalinae remains unclear.

Association of calling with endogenous and exogenous variables

Binary logistic regressions between female calling (occurring $v s$. not occurring) and both exogenous or environmental variables (light intensity ranging from 400 to 120,000 lux, wind speed from 0 to $5 \mathrm{~m} / \mathrm{s}$, and ambient temperature from 5 to $35^{\circ} \mathrm{C}$ ) and endogenous or physiological variables (female age) had different outcomes. The regressions with significant probabilities are detailed in Table 1. When considering all (exogenous and endogenous) variables, there was a significant correlation between calling and light intensity $(\mathrm{P} \leq 0.05)$ but not with wind speed, temperature, or age $(\mathrm{P}=0.70$; $\mathrm{P}=0.28 ; \mathrm{P}=0.40$, respectively). Unlike our results, a previous study in a Scarabaeidae (Coleoptera) had demonstrated a significant relationship between calling duration (not the binomial occurrence of this behavior as in our study) and wind speed (Facundo et al., 1999). There are also reports of a significant relationship between calling in several insects (including Tortricidae and Cerambycidae) and ambient temperature (Baker and Cardé, 1979; Bento et al., 1993, respectively). However, Soofbaf et al. (2007) found that Ectomyelois ceratoniae Zeller (Lepidoptera: Pyralidae) females called under laboratory conditions regardless of the temperature regime (between 20 to $30^{\circ} \mathrm{C}$ ), which is similar to the result we found in C. apicicornis, although the mechanism remains unclear. Regarding female age, it is possible that other physiological variables that were not studied here, such as nutrition and maturity, might affect calling, explaining the outcome of our study, but this aspect also remains unclear. Overall, these results are useful in determining several of the environmental and physiological conditions to optimize the collection of pheromones from calling females for subsequent studies. In our data, when all non-significant variables are excluded from the regression to simplify the model (parsimony principle), significance increases notably $(\mathrm{P} \leq 0.01)$, with a very small reduction in the concordance coefficient (proportion of concordant predictions and outcomes), which changed from $62 \%$ with all variables to $61 \%$ with non-significant variables removed. The probability for calling was minimally affected over the large range of light intensities tested. In fact, the probability only changed from 0.14 to 0.19 when the extreme values recorded were introduced into the adjusted model $\left[(\mathrm{P}\right.$ calling $/$ light intensity $)=1 /\left(1+\mathrm{e}^{(\mathrm{b} 0+\mathrm{blx})}\right)$, see Table 1 for parameters]. This result suggests that light most likely acts as a regulating (triggering) factor for calling but not necessarily as a function-parameter between calling and light intensity. A report supporting this hypothesis was published by Linsley (1959), who mentioned that mating behavior in some cerambycids occurs 
only under daylight illumination. Furthermore, Wang et al. (2002) demonstrated that mating is regulated by circadian rhythms in Nadezhdiella cantoni Cantoni (Coleoptera: Cerambycidae). Thus, light illumination is considered a necessary environmental condition during attempts to collect pheromones from calling females under laboratory conditions.

Regarding the time of day, in our studies, $C$. apicicornis of both sexes remained motionless during the scotophase and during most of the daylight hours, except during a clear peak of activities in both sexes between 9AM and 1PM (Figure 1). These data support the hypothesis of light as a triggering factor for sexual behavior in C. apicicornis and suggest that this time window would be the optimal time for collecting the pheromone from females and for testing the responses of males to pheromone sources.

\section{Oriented flights by males searching for females}

The oriented flight searching of $C$. apicicornis males $(n=43$, Figure 4$)$ towards calling females was characterized by the following steps: 1) taking off, TO, from the release cage and flying upwards above $2 \mathrm{~m}$; 2) circular flight, $\mathrm{CF}$, in which males fly around the female cage and make 2 or more circles of at least $2 \mathrm{~m}$ in diameter, approximately 2-4 m over the females; 3 ) zigzagging progressive flight, ZPF, in which males fly toward the source, with vertical zigzagging from approximately $1 \mathrm{~m}$ to $60 \mathrm{~cm}$ in amplitude while descending towards the caged female; 4) zigzagging stationary flight, $\mathrm{ZSF}$, in which the zigzagging is approximately $60 \mathrm{~cm}$ in amplitude or less, which then decreases to 5 to $10 \mathrm{~cm}$ in amplitude when approaching the female with a notable reduction in flight speed until remaining almost stationary a few $\mathrm{cm}$ from her; 5) landing on, LO, the female cage and remaining on it; and 6) searching, $\mathrm{S}$, for the female on the cage by walking actively and turning around within an area of approximately $5 \times 5 \mathrm{~cm}$, a few $\mathrm{cm}$ from the female. Searching was considered to have ended when the male reached the female. Unmated females keep calling despite approaches from males. A total of 209 sequences of males flying to and approaching calling females were recorded, lasting an average of $3 \pm 0.93 \mathrm{~min}$. Some of the steps in these sequences have been reported previously for other cerambycid species (e.g., Akutsu and Kuboki, 1983; Fettköther et al., 1995; Machado et al., 2006). However, ZPF and ZSF have not been mentioned before as part of the orientation sequences for cerambycids, but they are analogous to those of other flying insects that follow odor plumes (Kennedy, 1983), which is a behavior that maximizes the chance of reaching the source. Therefore, these behavioral steps observed in C. apicicornis strongly suggest the existence of a volatile, female-produced sex pheromone. Within the sequence, significant frequencies of transitions (from one step to any other) were used to build an ethogram (Figure 5). The steps (within the sequence) performed by most individuals included $\mathrm{TO}$ followed by ZPF, LO, and searching for females, but a few used other routes.

Table 1. Parameters of the significant binary logistic regressions: Female $(n=25)$ calling $v s$. light intensity (A), Male oriented flight searching vs.: "calling" postures (B), and Male oriented flight searching vs. female age (continuous between 1 and 6 days old $(n=22)$; then a few $(n=25) 10,12$, or 13 day old females performing "calling" postures $(\mathrm{C})$. Refer to the text for the sequence numbers.

\begin{tabular}{|c|c|c|c|c|c|c|}
\hline Dependent variable & Independent variable & $\mathrm{b}_{0}$ & $\mathrm{~b}_{1}$ & P-value & $\mathrm{OR}$ & $\mathrm{CC}$ \\
\hline A. Female calling & Light intensity & -1.74 & $1.13 \mathrm{e}^{-1 / 2}$ & $<0.01$ & 1.05 & 61.0 \\
\hline B. Male searching & Calling postures & -2.88 & 2.02 & $<0.01$ & 7.51 & 52.0 \\
\hline C. Male searching & Female age & -1.43 & -0.31 & 0.04 & 0.73 & 47.3 \\
\hline
\end{tabular}

$\mathbf{b}_{0}=$ constant $\mathrm{b}_{1}=$ slope $\mathrm{OR}=$ odds ratio $\mathrm{CC}=$ concordance coefficient. 

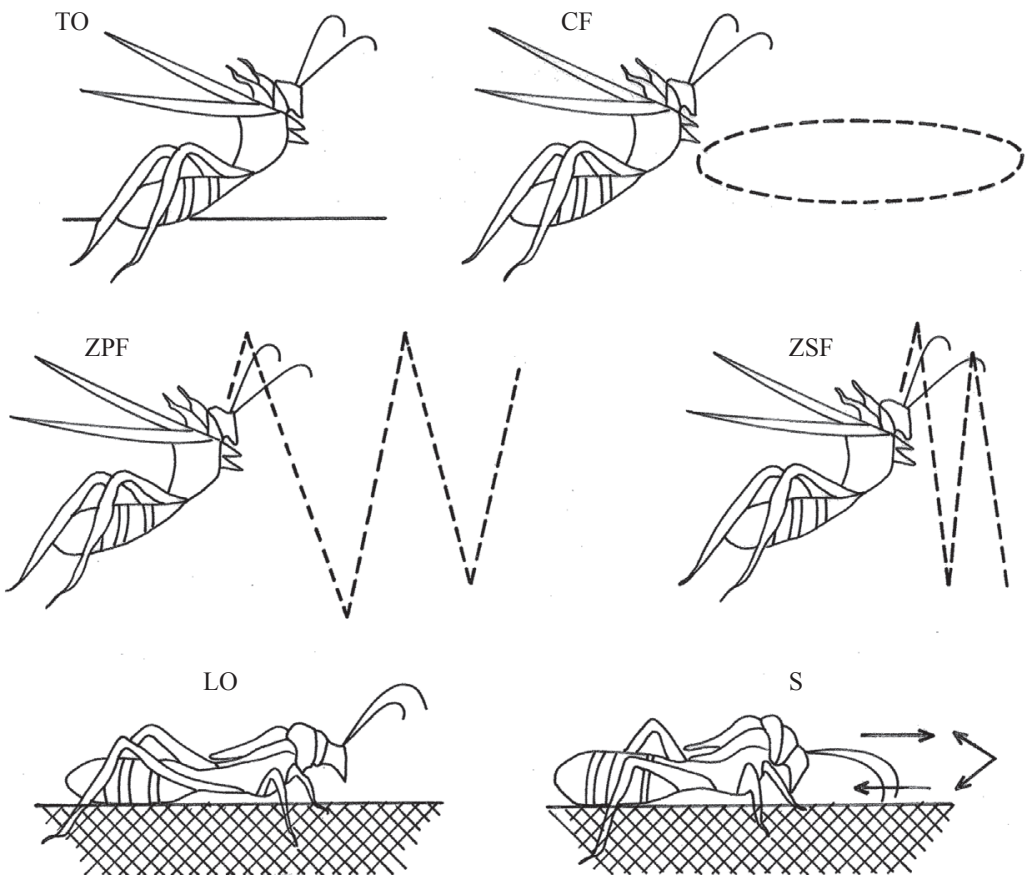

Figure 4. Drawing of the steps of the male orientation and searching sequence in response to calling females in C. apicicornis. Take off (TO); Circular flight (CF); Zigzagging progressive flight (ZPF); Zigzagging stationary flight (ZSF); Landing on (LO); and Searching (S).

Most insects also performed $\mathrm{CF}$ after TO and ZSF after ZPF; less than $10 \%$ of the test insects skipped these two later steps. Most individuals started to search for females immediately after they landed on the cage, but a few went back to the previous step (ZSF) and repeated the sequence before landing on the cage and searching again. The chi-square test for the complete sequence demonstrated a significant departure from independence (contingency coefficient: 0.87), indicating that these behaviors formed a non-random first order sequence. This sequence also had low variability (high repeatability) with an SI value of 0.90 , which is considered highly stereotyped (Ferrera, 2009). The model described for C. apicicornis male oriented flight searching is rare among the reproductive behavioral sequences described in cerambycids thus far. Most reports to date have focused on the responses of females to male-produced sex or aggregation pheromones (Lacey et al., 2009; Millar et al., 2009). To date, there have been relatively few reports of males responding to females, and all

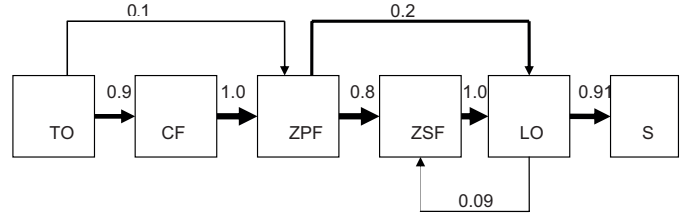

Figure 5. Ethogram for male orientation and searching toward calling females in C. apicicornis. Details are provided in Figure 4.

such reports have been for species belonging to primitive subfamilies within the Cerambycidae: Migdolus fryanus Westwood (subfamily Anoplodermatinae; Leal et al., 1994), Vesperus xatarti (Dufour-Mulsant) (Vesperinae; Cervantes et al., 2006), and P. californicus (Prioninae, Barbour et al., 2006; Rodstein et al., 2009). Our results represent one of the few cases of a cerambycid species in which males are supposedly attracted by a female-produced pheromone, and it is the first case of behavioral evidence for a pheromone of any type within the subfamily Necydalinae.

The characterization of both behaviors, female calling and male oriented flight searching, provides 
the background information required to begin a pheromone collection and identification project, thus allowing for the $C$. apicicornis pheromone to be developed for the monitoring and control of this insect species. This characterization also provides the base-line to evaluate male responses to pheromone sources.

Association between oriented responses by males and female calling and age

Male behavioral responses (oriented searching flights) toward females were highly correlated to female calling. A "virgin female calling" significantly increased the chances of males orientating towards her, with males orienting 7.51 times (see the odds ratio in Table 1, B) more often to calling than to non-calling females. Because males responded from relatively long distances ( $>3 \mathrm{~m}$ ) to females hidden in screen cages, it seems unlikely that visual signals are required during this phase of male orientation. Instead, either acoustic or chemical signals might be involved. Although no audible sounds were heard during the field observations, acoustic signals cannot be ruled out. However, our observations suggest that a female-produced long-range sex pheromone mediates this interaction because there are now a number of cerambycid species that have been shown to use sex pheromones, whereas no cerambycids have been shown to use acoustic signals for the long-distance attraction of mates. Furthermore, the stereotyped zigzag flight behaviors exhibited by males are very characteristic of insects responding to airborne pheromone plumes.

Only $52 \%$ of the oriented flights (concordance coefficient) were explained by the regression when correlated to calling postures. However, this relatively low correlation could be due to several factors. For example, pheromone release is unlikely to be constant, and consequently, females producing relatively low amounts of the pheromone would be less attractive to males.
Conversely, females that were not actively calling may still be attractive to males because of residual pheromone that was adsorbed and slowly released from the cuticular waxes.

Our results also suggested that younger virgin females were significantly more attractive to males than older females ( $\mathrm{P}=0.04$, Table $1 \mathrm{C})$. However, these results seem to be unrelated to the calling frequency. To test this idea, a contingency table was used to contrast the female age categories (younger, 1-3 days old, and older individuals, 4-6 days old) $v s$. the frequency of calling sequences/observation period ( $>4$ calls/ observation period and $\leq 4$ calls). The numbers of both older females performing 5 or more calls per period and younger females performing 4 or less calls per period were highly significantly greater than the expected value $\left(\chi^{2}=16.2, \mathrm{P}=\right.$ $0.001)$. Thus, older females would be less attractive despite the fact that they called more frequently. Similar situations, in which younger females call less but are more attractive than older females, have been observed in other insects such as the lepidopteran Phyllocnistis citrella Stainton (Jacas and Peña, 2002). These results may be due to the depletion of limited reserves of pheromones by older females or age-related changes in the pheromone blend and confirm that young virgin females should be used for the collection of air volatiles in attempts to capture and identify the C. apicicornis sex pheromone.

\section{Acknowledgements}

The authors would like to acknowledge Conicyt (Comisión Nacional de Investigación Científica y Tecnológica of Chile) for funding the project Fondecyt 11070072, "Caracterización del comportamiento de llamado, orientación y cortejo en Callisphyris apicicornis (Coleoptera: Cerambycidae) y evaluación de la respuesta de machos a volátiles aislados desde hembras vírgenes conespecíficas". 


\section{Resumen}

T. Curkovic y C. Ferrera 2012. Comportamiento de llamado, en hembras, y de vuelo orientado y búsqueda, en machos de Callisphyris apicicornis: Evidencia de una feromona sexual producida por la hembra. Cien. Inv. Agr. 39(1): 147-158. Callisphyris apicicornis es una plaga creciente de frutales en Chile. Como un pre-requisito para identificar su feromona sexual para eventualmente usarla en manejo, se filmó el comportamiento de "llamado" (emisión de feromonas) en hembras y el de "orientación y búsqueda" de machos hacia hembras llamando. Se registró también la intensidad de luz, velocidad del viento, hora del día y la frecuencia de individuos haciendo cada paso dentro de la respectiva secuencia de comportamiento. Se proporcionan también dibujos de las secuencias y etogramas (con rutas y retornos), incluyendo las frecuencias de transición entre pasos. El comportamiento de llamado en hembras mostró movimientos característicos del abdomen, patas, élitros y alas, similares a los descritos en otras especies de cerambícidos en las cuales la hembra llama. El comportamiento de orientación y búsqueda en machos incluyó vuelos en zig-zag (característicos en insectos que responden a plumas de feromona transportadas por el viento), aterrizaje y búsqueda de las hembras enjauladas. Las hembras llamaron, y los machos respondieron, principalmente entre las 9 AM y la 1 PM. Ambos comportamientos no ocurrieron en forma azarosa y fueron estereotipados. El "llamado" fue significativamente afectado por la luz (aparentemente actúa gatillando la conducta), lo que no ocurrió con la velocidad del viento, temperatura ambiental y edad de las hembras. Los machos respondieron más fuertemente a hembras más jóvenes, aunque ellas "llamaron" significativamente menos que las más viejas. Estos resultados apoyan la hipótesis de la existencia de una feromona sexual producida por la hembra de C. apicicornis y proveen información de respaldo para intentar su colecta e identificación. La caracterización del comportamiento de machos proporciona una línea base que servirá para comparar experimentos donde se evalúe la actividad de compuestos que supuestamente correspondan a la feromona de esta especie. Este es uno de los primeros reportes de una especie de cerambícido donde la hembra llama y el macho responde consecuentemente a ella, y es el primero sobre la caracterización del comportamiento de llamado y del de orientación y búsqueda en un Necydalinae.

Palabras clave: Comportamiento sexual, Cerambycidae, edad de insectos, feromonas, intensidad de luz.

\section{References}

Akutsu, K., and M. Kuboki. 1983. Mating behavior of the Udo longicorn beetle, Acalolepta luxuriosa Bayes (Coleoptera: Cerambycidae). Japanese Society of Applied Entomology and Zoology 27: 189-196.

Artigas, J. 1994. Callisphyris vespa Fairmaire \& Germain. Sierra del manzano. In: Entomología económica. Insectos de interés agrícola, forestal, médico y veterinario (nativos, introducidos y susceptibles de ser introducidos), Volumen II. Primera Edición. Ediciones U. de Concepción. Concepción, Chile. pp. 140-141.

Baker, T.C., and R.T. Cardé. 1979. Analysis of pheromone-mediated behaviors in male Grapholita molesta, the oriental fruit moth (Lepidoptera: Tortricidae). Environmental Entomology 8:956968.

Barbour, J., E. Cervantes, E. Lacey, and L. Hanks. 2006. Calling behavior in the primitive longhorned beetle Prionus californicus Mots. Journal of Insect Behavior 19: 623-629.

Barriga, J., T. Curkovic, T. Fichet, J. Henríquez, and J. Macaya. 1993. Nuevos antecedentes de coleópteros xilófagos y plantas hospederas en Chile, con una recopilación de citas previas. Revista Chilena de Entomología 20: 65-91.

Bento, J.M., T.M. Dellalucia, and R.T. Frighetto. 1993. Male response to natural sex pheromone of Migdolus fryanus Westwood (Coleoptera, Ce- 
rambycidae) female as affected by daily climatic factors. Journal of Chemical Ecology 19: 23472351.

Bousquet, Y., D. Heffern, P. Bouchard, and E. Nearns. 2009. Catalogue of family-group names in Cerambycidae (Coleoptera). Zootaxa 2321: 1-80.

Cerda, M. 1986. Lista sistemática de los cerambícidos chilenos (Coleoptera: Cerambycidae). Revista Chilena de Entomología 14:29-39.

Cervantes, D., L. Hanks, E. Lacey, and J. Barbour. 2006. First documentation of a volatile sex pheromone in a longhorned beetle (Coleoptera: Cerambycidae) of the primitive subfamily Prioninae. Annals of the Entomological Society of America 99: 719-722.

Connor, W., and B. Best. 1988. Biomechanics of the release of sex pheromones in moths: effects of body posture on local airflow. Physiological Entomology 13: 15-20.

Curkovic, T. 2008. La sierra del manzano: Antecedentes biológicos y bases para el desarrollo del control de adultos. Aconex 98: 10-14.

Curkovic, T., and C. Ferrera. 2008. Manejo etológico de plagas nativas en Chile en base al estudio de su comportamiento y química ecológica. Revista Antumapu (Chile) 5: 3-5.

Curkovic T., and J. Muñoz. 2011. Caracterización del cortejo y cópula en Callisphyris apicicornis: herramienta para definir la viabilidad para desarrollar estrategias de manejo. Agrociencia 45: 453-464.

Facundo, H., C. Linn, M. Villani, and W. Roelofs. 1999. Emergence, mating, and postmating behaviors of the Oriental beetle (Coleoptera: Scarabaeidae). Journal of Insect Behavior 12: 175-192.

Fagen, R., and D. Young. 1978. Temporal patterns of behaviors: durations, intervals, latencies, and sequences. In: Colgan, P. (ed.). Quantitative ethology. First Edition. Wiley. New York, USA. p. 100-107.

Ferrera, C. 2009. Análisis del comportamiento de llamado y orientación hacia el compañero sexual en Callisphyris apicicornis F. \& G. y asociación del llamado con variables ambientales y edad de las hembras en campo. Tesis de Magíster. Facultad de Ciencias Agronómicas, Universidad de Chile. Santiago, Chile. 62 pp.
Fettköther, R., K. Dettner, F. Schroder, H. Meyer, W. Francke, and U. Noldt. 1995. The male pheromone of the old house borer Hylotrupes bajulus (L.) (Coleoptera, Cerambycidae) identification and female response. Experientia 51: 270-277.

Hall, D., S. Cork, S. Phythian, S. Chittamuru, B. Jayarama, M. Venkateshia, and K. Sreedharan. 2006. Identification of components of male-produced pheromone of coffee white stemborer, $X y$ lotrechus quadripes. Journal of Chemical Ecology 32: 195-219.

Haynes, K., and M. Birch. 1984. Mate-locating and courtship behaviors of the artichoke plume moth, Platyptilia carduidactyla (Lepidoptera: Pterophoridae). Environmental Entomology 13: 399-408.

Jacas, H., and J. Peña. 2002. Calling behavior of two different field populations of Phyllocnistis citrella (Lepidoptera: Gracillariidae): effect of age and photoperiod. Florida Entomologist 85: 378-381.

Kennedy, J. 1983. Zigzagging and casting as a programmed response to wind-borne odour: a review. Physiological Entomology 8: 109-120.

Lacey, E., J. Matthew, J. Ginzel, J. Millar, and L. Hanks. 2004. Male-produced aggregation pheromone of the cerambycid beetle Neoclytus acuminatus acuminatus. Journal of Chemical Ecology 30: 1493-1507.

Lacey, E., J. Millar, J. Moreira, and L. Hanks. 2009. Male-produced aggregation pheromones of the cerambycid beetles Xylotrechus colonus and $\mathrm{Sa}$ rosesthes fulminans. Journal of Chemical Ecology 35:733-740.

Leal, W., J. Bento, E. Villela, and T. Dellalucia. 1994. Female sex pheromone of the longhorn beetle Migdolus fryanus Westwood: N-(2'S)-methylbutanoyl 2-methylbutylamine. Experientia 50: 853-856.

Linsley, E. 1959. Ecology of Cerambycidae. Annual Review of Entomology 4: 99-138.

Machado, L., M. Habib, L. Leite, e J. Mendes. 2006. Estudos ecológicos e comportamentais de Migdolus fryanus (Westwood, 1863) (Coleoptera: Vesperidae), em cultura de cana-de-açúcar, em quatro municípios do estado de São Saulo. Arquivos do Instituto Biologico (Sao Paulo) 73: 227-233. 
Michelsen, A. 1965. On the evolution of tactile stimulations in longhorned beetles (Cerambycidae, Coleoptera). Zeitschrift für Tierpsychologie 23: 257-266.

Millar, J., L. Hanks, J. Moreira, J. Barbour, and E. Lacey. 2009. Pheromone chemistry of cerambycid beetles. In: Nakamuta K., and Millar J. (eds.). Chemical Ecology of Wood-boring Insects. First Edition. Forestry and Forest Products Research Institute, Ibaraki, Japan. pp. 52-79.

Mondor, E., and J. Roland. 1998. Host searching and oviposition by Leschenaultia exul, a tachinid parasitoid of the forest tent caterpillar, Malacosoma disstria. Journal of Insect Behavior 11: 583-591.

Mori, K., and Y. Saito. 2005. Communal relationships in a social spider mite, Stigmaeopsis longus (Acari: Tetranychidae): an equal share of labor and reproduction between nest mates. Ethology 112: 134-142.

Ray, A., E. Lacey, and L. Hanks. 2006. Predicted taxonomic patterns in pheromone production by longhorned beetles. Naturwissenschaften 93 : 543-550.

Rodstein, J., J. McElfresh, J. Barbour, A. Ray, L. Hanks, and J. Millar. 2009. Identification and synthesis of a female-produced sex pheromone for the cerambycid beetle Prionus californicus. Journal of Chemical Ecology 35: 590-600.

Soofbaf, M., G. Nouri, S. Goldansaz, and R. AsghariZakaria. 2007. Effects of age and temperature on calling behavior of carob moth, Ectomyelois ceratoniae Zell. (Lepidoptera: Pyralidae) under laboratory conditions. Pakistan Journal of Biological Sciences 10: 2976-2979.

Visauta, B. 2007. Análisis estadístico con SPSS para Windows. McGraw-Hill. Madrid, España. 283 pp.

Wang, Q., W. Zeng, L. Chen, J. Li, and X. Yin. 2002. Circadian reproductive rhythms, pair-bonding, and evidence for sex-specific pheromones in $\mathrm{Na}$ dezhdiella cantori (Coleoptera: Cerambycidae). Journal of Insect Behavior 15: 527-539. 